5 Mancini JGB, Goldberger AL. Cardioversion of atrial fibrillation: consideration of embolization, anticoagulafibrillation: consideration of embolization, anticoagulation, prophylactic pacema
Heart $J$ 1982;104:617-21.

6 Lovett JL, Sandok BA, Giulani ER, Nasser FN. Twodimensional echocardiography in patients with focal cerebral ischemia. Ann Intern Med 1981;95:1-4.

7 Knopman DS, Anderson DC, Asinger RW, Greenland P, Mikell F, Good DC. Indications for echocardiography in patients with ischemic stroke. Neurology 1982;32 1005-11.

8 Aschenberg W, Schluter M, Kremer P, Schroder E, Siglow $V$, Bleifeld $W$. Transoesophageal two-dimensional echocardiography for the detection of left atrial appendage thrombus. J Am Coll Cardiol 1986;7:163-6.

9 Zenker G, Erbel R, Kramer G, et al. Transoesophageal twodimensional echocardiography in young patients with cerebral ischemic events. Stroke 1988;19:345-8.

10 Daniel WG, Angermann C, Engberding R, et al. Transoesophageal echocardiography in patients with cerebral
ischemic events and arterial embolism-a European ischemic events and arterial embolism - a European II):II-473.

11 Pop G, Sutherland GR, Koudstaal PJ, Sit TW, de Jong G, Roelandt JRTC. Transoesophageal echocardiography in the detection of intracardiac embolic sources in patient with transient ischemic attacks. Stroke 1990;21:560-5.

12 Seward JB, Khandheria BK, Oh JK, et al. Transoesophageal echocardiography: technique, anatomic correlations, implementation and clinical applications. Mayo Clin Pro 1988;63:649-80.

13 Beppu S, Nimura Y, Sakakibara H, et al. Smoke-like echo in the left atrial cavity in mitral valve disease: Its features and significance. J Am Coll Cardiol 1985;6:744-9.

14 Daniel WG, Nellessen U, Schroder E, et al. Left atrial spontaneous echo contrast in mitral valve disease: an indicator for an increased thromboembolic risk. J Am Coll Cardiol 1988;11:1204-11.

15 Hatle L, Angelsen B, Tromsdal A. Non-invasive assessment of atrioventricular pressure half-time by Doppler of atrioventricular pressure half-time

16 Lechat P, Mas JL, Lascault G, et al. Prevalence of patent foramen ovale in patients with stroke. N Engl J Med 1988; 318:1148-52.
17 Nobuyoshi M, Hamasaki N, Kimura T, et al. Indications, complications, and short-term clinical outcome of percutaneous transvenous

18 Humphrey PRD, Harrison MJG. How often can an embolic stroke be diagnosed clinically? A clinicopathological stroke be diagnosed clinically? A clinicopat
correlation. Postgrad Med J 1985;61:1039-42.

19 Ramirez-Lassepas M, Cipolle RJ, Bjork RJ, et al. Can embolic stroke be diagnosed in the basis of neurologic embolic stroke be diagnosed in the basis

20 Sherman DG, Dyken ML, Fisher M, Harrison MJG, Hart RG. Cerebral embolism. Chest 1986;89(suppl 2): 82S-98S

21 Shrestha NK, Moreno FL, Narciso FV, Torres L, Calleja HB. Two-dimensional echocardiographic diagnosis of left atrial thrombus in rheumatic heart disease. A clinicopathologic study. Circulation 1983;67:341-7.

22 Bansal RC, Heywood JT, Applegate PM, Jutzy KR. Detection of left atrial thrombi by two-dimensional echocardiography and surgical correlation in 148 patients with mitral valve disease. Am J Cardiol 1989;64:243-6.

23 Jacobs NH, Whyte S, Kelleher AD, Juarez CC, Garrick R, Feneley MP. Limited role of transesophageal echocardiography in unselected patients with cerebral ischaemic diography in unselected patients with cerebral iI):III-110.

24 Siel $B$ ablu , blood durin

25 Mikell FL, Asinger RW, Elsperger KJ, Anderson WR Hodges $M$. Regional stasis of blood in the dysfunctional Hodges $M$. Regional stasis of blood in the dysfunctional left ventricle: echocardiographic detection and differentia-

26 Mahoney C, Sublett KL, Harrison MR. Resolution of Mahoney C, Sublett KL, Harrison MR. Resolution of
spontaneous contrast with platelet disaggregatory therapy spontaneous contrast with platelet disaggregatory
(trifluoperazine). Am J Cardiol 1989;63:1009-10

27 Matsumura M, Shah P, Kyo S, Omoto R. Advantages of transesophageal echo for correct diagnosis on small left atrial thrombi in mitral stenosis [abstract]. Circulation 1989;80(suppl II):II-678.

28 Petersen P, Boysen G, Godtfredsen J, Andersen ED Andersen B. Placebo-controlled, randomised trial of warfarin and aspirin for prevention of thromboembolic complications in chronic atrial fibrillation: The Copenhagen AFASAK study. Lancet 1989;i:175-9.

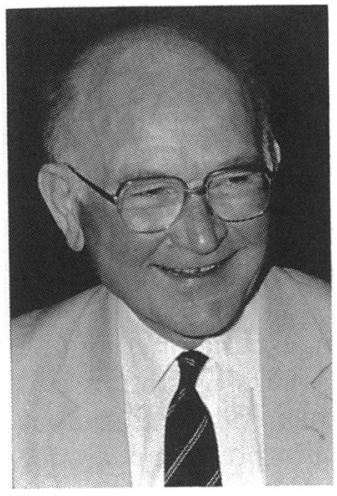

\section{EIRIAN WILLIAMS}

Bill Williams, MD, FRCP, died on 31 March, aged 65 , after a long struggle against an aggressive prostatic carcinoma. He spent 30 years as physician in general medicine and cardiology at Withybush Hospital, Haverfordwest, Pembrokeshire. He was a member of the Association of Physicians of Great Britain and Ireland and of the British Cardiac Society.

$\mathrm{He}$ was an international authority on brucellosis and published several papers on this topic in the Lancet in the 1970s. It was appropriate that he was asked to give the Donald Hunter Memorial Lecture to the Royal College of Physicians on this topic since Hunter was one of his mentors at the London Hospital and a lifelong friend.
Apart from being a dedicated and gifted clinician his main achievement was the creation of Withybush General Hospital in Haverfordwest, Pembrokeshire, which resulted out of his single-minded efforts. His contributions to postgraduate medicine in the area were recognised when the library in the postgraduate centre was named after him.

He will be remembered with affection by his many friends as an accomplished gardener, no mean wet fly fisher, and as a man who never gave up a cause-be it the developmment of his hospital or of academic cardiology in Cardiff. $\mathrm{He}$ is survived by his wife, three children, and seven grandchildren.

REG HALL 